\title{
PENGEMBANGAN MODEL PEMBELAJARAN PRAKTIK BERBASIS KOMPETENSI BERORIENTASI PRODUKSI
}

\author{
R. Mursid \\ FT Universitas Negeri Medan \\ email: mursid.tp@gmail.com
}

\begin{abstract}
Abstrak: Penelitian ini bertujuan untuk mengembangkan model pembelajaran praktik berbasis kompetensi berorientasi produksi yang layak digunakan dalam pembelajaran praktik dan efektif dapat meningkatkan hasil belajar mahasiswa pada mata kuliah teknologi permesinan. Hasil penelitian dan pengembangan menunjukkan bahwa (1) model pembelajaran dapat meningkatkan kompetensi mahasiswa yang berorientasi produksi; (2) model pembelajaran tersebut efektif dapat meningkatkan hasil belajar pada pembelajaran praktik; (3) model pembelajaran tersebut dapat menciptakan iklim belajar yang memposisikan mahasiswa sebagai centre learning dengan segala aktivitas yang dilakukannya, memotivasi belajar mahasiswa melalui ide-ide yang konstruktif, mendorong dan membangkitkan keberanian belajar dan bekerja yang didasari komitmen yang tinggi dan berdisiplin, meningkatkan kecepatan belajar, motivasi belajar, semangat belajar, kerja sama kelompok, kreatifitas, dan inovasi.
\end{abstract}

Kata Kunci: model pembelajaran praktik, berbasis kompetensi, orientasi produksi

\section{DEVELOPMENT OF PRACTICE LEARNING MODEL COMPETENCY-BASED ORIENTED PRODUCTION}

\begin{abstract}
This research aims to develop practice learning model competency-based production oriented which is fit for use in teaching practice and effective can improve student learning outcomes on subjects machining technology. Results of research and development show that (1) the instructional can improve student competency-oriented production; (2) the instructional model can effectively improve learning outcomes in practice learning; (3) the learning modelcan be; create a learning climate which is positioning as a student learning center with all the activities done, motivate students to learn through constructive ideas, facilitate and encourage the willness to learn and work which is based on a strong commitment and disciplined, increase the speed of learning, motivation to learn, enthusiasm for learning, teamwork, creativity, and innovation.
\end{abstract}

Keywords: models of practice learning, competency-based, orientation of production

\section{PENDAHULUAN}

Pembelajaran di perguruan tinggi selain menuntut kemampuan akademik (hard skill), mahasiswa juga dituntut untuk dapat meningkatkan kemampuan personal (soft skills) sehingga mahasiswa siap memasuki dunia kerja yang sesungguhnya setelah menyelesaikan studi. Pendidikan bidang keteknikan, seperti pendidikan teknik mesin, hendaknya selain memberikan teori-teori yang cukup, juga perlu memberikan praktik dan contoh-contoh pemecahan proyekproyek nyata dengan memanfaatkan model, stra- tegi, metode, dan media pembelajaran yang mendukung. Pada abad pengetahuan saat ini, paradigma belajar berorientasi pada proyek, masalah, penyelidikan (inquiry), penemuan dan penciptaan" (Wilson, 1996:34). Hal ini berarti memberikan kesempatan kepada mahasiswa untuk mengarungi seluruh ranah pembelajaran (kognitif, afektif, dan psikomotor), serta mengembangkan seluruh kecerdasannya (emosional, spiritual, sosial, dan sebagainya).

Pembelajaran praktik belum secara serius dikembangkan berdasarkan prinsip-prinsip yang 
sahih untuk memberikan peluang mahasiswa belajar cerdas, kritis, kreatif, inovatif, dan memecahkan masalah. Pembelajaran praktik yang diupayakan dosen pendidikan teknik mesin belum menunjukkan sebagai suatu proses pengembangan kreativitas mahasiswa. Hasil pengamatan awal menunjukkan adanya kecenderungan dosen dalam memilih dan menggunakan metode pembelajaran praktik yang bersifat spekulatif, yang berakibat kegiatan pembelajaran praktik kurang menarik, membosankan, tidak menantang, produk yang dihasilkan tidak maksimal, dan kecenderungan gagal, tidak layak jual, sulit mencapai target, tidak berorientasi produksi.

LPTK-PTK (Lembaga Pendidikan Tenaga Kependidikan Pendidikan Teknologi Kejuruan) mempunyai tanggung jawab dalam menghasilkan guru yang berkualitas. Pada tatanan lokal dengan penerapan otonomi daerah, LPTKPTK mempunyai peluang untuk menata pengembangan tenaga guru lebih berkualitas sesuai dengan tuntutan kebutuhan daerah. Orientasi baru pendidikan itu berkehendak menjadikan lembaga pendidikan sebagai kecakapan hidup, dengan pendidikan yang bertujuan mencapai kompetensi, melalui proses pembelajaran yang autentik dan kontekstual yang dapat menghasilkan produk bernilai dan bermakna bagi mahasiswa. Selainitu, juga pemberian layanan pendidikan berbasis luas melalui berbagai jalur dan jenjang pendidikan yang fleksibel multi-entrymulti-exit.

Permasalahan utama dalam pembelajaran di perguruan tinggi adalah bagaimana perencanaan dan kesiapan dosen untuk mengelola pembelajaran agartercapai kompetensi yang diinginkan dalam diri mahasiswa. Secara konseptual, barangkali pengembangan strategi pembelajaran dapat diakui sebagai salah satu sarana bagi lembaga pendidikan untuk memberikan dan memperluas wawasan pembelajar tentang pengetahuan, keterampilan, dan nilai-nilai dasar lainnya dengan harapan dapat direfleksikan dalam kebiasaan berpikir dan bertindak.

Peningkatan kualitas dan proses pembelajaran diperguruan tinggi perlu secara kreatif mengembangkan konsep-konsep pendidikan baru yang lebih komprehensif sekaligus kompe- titif. Hal ini dapat dilakukan dengan pembaharuan metode pembelajaran yang lebih fleksibel, dengan menempatkan mahasiswa sebagai subjek (student-centered learning $=$ SCL), dibandingkan sebagai objek pendidikan. Konsep pendidikan juga perlu didesain untuk menumbuhkan semangat kewirausahaan dan peningkatan soft skills serta success skills sehingga lulusan perguruan tinggi mempunyai karakter percaya diri yang tinggi, memiliki kearifan terhadap nilai-nilai sosial dan kultural bangsa, kemandirian serta leadership yang kuat (HELTS, 2004: 22).

perguruan tinggi mengacu pada standardisasi proses pembelajaran yang diharapkan ada pembaharuan pembelajaran yang inovatif. Oleh karena itu, penelitian ini berupaya mengembangkan model pembelajaran untuk mengembangkan kreativitas mahasiswa, terutama aspek berfikir kreatif, inovatif, dan produktif, yang diharapkan mampu meningkatkan kualitas pembelajaran dan pendidikan, sekaligus mampu meningkatkan kompetensi praktik mahasiswa di bidang pendidikan teknik mesin.

Proses pembelajaran LPTK-PTK (2003: 2) diarahkan kepada: (1) kegiatan pembelajaran perlu memperhatikan perbedaan kemampuan individu dan dapat mengembangkan bakat dan potensi mahasiswa dalam bidang keahlian secara optimal (competency based learning); (2) kegiatan pembelajaran ditekankan pada pemberian pengalaman nyata dalam kehidupan sehari-hari sesuai dengan kebutuhan dunia kerja dan terkait dengan penerapan konsep, kaidah, dan prinsip disiplin ilmu yang dipelajari; (3) pembelajaran perlu diarahkan untuk mendorong mahasiswa dapat mengkomunikasikan kreasi temuannya kepada masyarakat luas sehingga dapat mengembangkan empati dengan menyelaraskan pengetahuan yang dimiliki dengan tindakannya; dan (4) pembelajaran diarahkan untuk menciptakan iklim kompetisi sehingga dapat menghasilkan karya-karya yang inovatif dan produktif.

Pembelajaran berbasis kompetensi mempunyai implikasi yang luas dengan menggunakan pendekatan competency based yang didasarkan pada dua filosofi dasar. Pertama, gagasan human competence merupakan kemampuan 
yang benar-benar terlihat. Pengetahuan, sikap, dan keterampilan merupakan hal yang tidak berharga jika tidak ditunjukkan dengan adanya hasil. Kedua, di dalam mastery learning disebutkan bahwa hampir semua orang dapat mempelajari semua hal dengan baik apabila mendapatkan pembelajaran yang berkualitas serta waktu yang mencukupi. Kurikulum berbasis kompetensi mencakup beberapa kompetensi yang harus dimiliki oleh mahasiswa calon guru antara lain: (1) kompetensi kognitif yang meliputi pengetahuan dan pemahaman khusus; (2) kompetensi afektif yang meliputi hal-hal yang berkenaan dengan nilai-nilai, sikap, interes, dan apresiasi; (3) kompetensi kinerja sampai pada kemampuan mendemontrasikan perilaku atau keterampilan; (4) kompetensi hasil berupa kemampuan untuk menghasilkan perubahan dalam bentuk lain; dan (5) kemampuan berapresiasi (Unimed, 2004:4).

Nordhaug (1998:8-19), bahwa kompetensi terdiri atas pengetahuan tentang metode, proses, dan teknik yang dirancang untuk melaksanakan tugas tertentu dan kemampuan menggunakan alat-alat dan perlengkapannya. Artinya, kompetensi dalam pengertian spesifik dan teknis mencakup pengetahuan prinsip kerja dan prosedur kerja, serta kemampuan mengoperasikan alat untuk melaksanakan tugas atau pekerjaan tertentu. Bowden \& Masters (1993:39) secara tegas mengatakan bahwa kompetensi harus didefinisikan sebagai suatu yang betul-betul dapat dilakukan seseorang, bukan suatu yang telah diperoleh dari pembelajaran yang belum tentu dapat dilakukan. Hal ini berarti kompetensi menunjuk pada kemampuan unjuk kerja seseorang. Preston \& Walker (1993:127) memberikan definisi kompetensi dengan pendekatan holistik sebagai kombinasi pengetahuan, keterampilan dan sikap yang memungkinkan seseorang dapat melakukan tugasnya.

Joyce \& Weil(1996:46) menjelaskan bahwa model pembelajaran adalah suatu perencanaan yang digunakan sebagai pedoman dalam merencanakan pembelajaran di kelas atau pembelajaran dalam tutorial dan untuk menentukan perangkat-perangkat pembelajaran serta mengarahkan kita dalam mendesain pembelajaran untuk membantu pebelajar sedemikian hingga tujuan pembelajaran tercapai. Model pembelajaran menurut Joice \& Weil (1996:20) adalah suatu perencanaan atau pola yang dapat digunakan untuk kurikulum (materi pembelajaran yang panjang), mendesain materi pembelajaran, dan untuk mengantarkan pembelajaran di dalam maupun di luar kelas.

Model-model pembelajaran menurut taksonomi Gustafson \& Branch (2003:112) dibagi menjadi empat kategori, yaitu model yang berorientasi pada kelas, produk, sistem, dan organisasi. Menurutnya, model pembuatan produk mempunyai tiga karakteristik utama, yaitu: (1) adanya asumsi bahwa produk pembelajaran diperlukan; (2) diperlukan uji coba dan revisi berulang kali hingga mantap; dan (3) adanya asumsi bahwa produk itu harus dapat digunakan oleh berbagai pengelola pembelajaran. Berkaitan dengan model pembuatan produk, seperti modul dan/atau bahan ajar pembelajaran, model pembelajaran yang dijadikan landasan pengembangan adalah Model Dick \& Carey dan model lain yang dianggap relevan. Dapat dilihat bahwa saat ini dibutuhkan suatu model pembelajaran yang mampu lebih memberdayakan mahasiswa dalam mencapai kompetensi yang diinginkan.

Komponen utama teori pembelajaran menurut Reigeluth (1983:22), yang diperlukan dalam pengembangan model pembelajaran, yaitu: metode, kondisi, dan hasil. Metode pembelajaran adalah berbagai macam cara untuk mencapai berbagai macam hasil dalam berbagai macam kondisi. Kondisi pembelajaran merupakan faktor yang mempengaruhi dampak metode, oleh karena itu penting untuk menentukan metode. Hasil pembelajaran merupakan berbagai akibat yang dapat dipakai untuk mengukur kegunaan berbagai macam metode dalam berbagai kondisi. Strategi pembelajaran (instructional strategy) adalah suatu perencanaan untuk membantu pembelajar melalui berbagai usaha untuk mencapai setiap tujuannya.

Selanjutnya, Seels \& Richey (1994:31) mengatakan bahwa strategi pembelajaran adalah spesifikasi untuk memilih dan mengurutkan proses dan kegiatan-kegiatan dalam suatu pelajaran. Dick \& Carey (2005:190-198) menyata- 
kan bahwa strategi pembelajaran menjelaskan komponen umum dari satu set materi dan prosedur pembelajaran yang akan digunakan dengan bahan lain untuk menghasilkan hasil belajar tertentu dari pihak pebelajar. Strategi pembelajaran mempunyai lima komponen, yakni: (1) kegiatan pra instruksional; (2) penyajian informasi; (3) partisipasi mahasiswa; (4) tes; dan (5) tindak lanjut.

Kegiatan pembelajaran menurut Dick \& Carey (2005:189) yaitu; (1) memberikan motivasi atau menarik perhatian; (2) menjelaskan tujuan pembelajarankepada mahasiswa; (3) mengingatkan kompetensi prasyarat; (4) memberi stimulus (masalah, topik, konsep); (5) memberi petunjuk belajar (cara mempelajari); (6) menimbulkan penampilan mahasiswa; (7) memberi umpan balik; (8) menilai penampilan; dan (9) penyimpulkan. Semua aspek tersebut digunakan dalam pelaksanaan startegi pembelajaran praktik yang dikembangkan dalam pengembangan model pembelajaran. Hal yang sama dikemukakan oleh Arends (2004:97-100) bahwa dalam perencanaan pembelajaran yang baik harus dapat melibatkan kegiatan pengalokasian penggunaan waktu, memilih metode pembelajaran yang tepat guna, menciptakan minat mahasiswa, dan membangun lingkungan belajar yang produktif. Bahkan, dalam perencanaan yang saksama dibutuhkan untuk banyak aspek kehidupan modern. Namun, perencanaan pembelajaran juga dapat memiliki konsekuensi yang tidak diinginkan, yakni menyebabkan dosen tidak sensitif terhadap kebutuhan dan ide-ide mahasiswa.

Pengintegrasian teknologi untuk pengembangan program pembelajaran sejalan dengan pendapat Jones dan Davis (via Khosrow 2011: 102), alasan mengintegrasikan teknologi ke dalam proses pendidikan karena ada kebutuhan untuk merencanakan pembelajaran yang akan memotivasi mahasiswa untuk belajar. Desain pembelajarannya adalah (1) profesi yang penting; (2) berfokus pada membangun dan mempertahankan kinerja manusia yang efisien dan efektif; (3) dipandu oleh model kinerja; (4) dilakukan secara sistematis; (5) berdasarkan teori sistem terbuka; dan (6) berorientasi untuk mencari dan menerapkan solusi yang efektif. Tujuan desain pembelajaran adalah untuk meningkatkan kinerja mahasiswa dan efisiensi dan efektivitas belajar (Rothwell dan Kazanas, 2004:3-5). Sebagai bagian dari teknologi pembelajaran sistem yang diciptakan oleh manusia untuk sesuatu tujuan tertentu, yang pada intinya adalah untuk mempermudah manusia dalam memperingan usahanya, meningkan hasilnya, serta menghemat tenaga serta sumber daya yang ada (Miarso, 2007:4). Dengan demikian, dapat disikapi bahwa pemanfaatan teknologi pembelajaran adalah untuk mempermudah upaya peningkatan sumber daya manusia organisasi dalam meningkatkan kinerja.

Aktivitas pengembangan pembelajaran praktik merupakan suatu pengembangan model. Model pembelajaran adalah rangkaian komponen-komponen strategi pembelajaran yang terintegrasi, antara lain komponen: (1) pentahapan dan urutan ide isi materi; (2) penggunaan ikhtisar dan ringkasan; (3) penggunaan contoh; (4) penggunaan praktik; (5) dan penggunaan strategi yang berbeda-beda untuk memotivasi siswa. Suatu model pembelajaran memperlihatkan seluruh aspek pembelajaran yang berbeda-beda dalam rangka meraih hasil belajar terbaik melalui antisipasi kondisi belajar tertentu yang dideskripsikan secara detail (Reigeluth, 1983:21). Menurut Prosser (1950:223), pendidikan kejuruan akan efektif jika dosennya telah mempunyai pengalaman yang sukses dalam penerapan keterampilan dan pengetahuan pada operasi proses kerja yang akan dilakukan. Hal ini menunjukkan bahwa bekal pengalaman bagi dosen sangat penting dalam mentransfer pengetahuan dan keterampilan kepada mahasiswa yang akan langsung terjun ke dunia kerja.

Pada penelitian dan pengembangan ini, yang dilakukanadalah:(1) mengembangkan model pembelajaran praktik berbasis kompetensi berorientasi produksi (berupaya untuk mencapai efisiensi produksi yang tinggi, biaya yang rendah dan distribusi secara masal dengan kualitas produk yang bermutu/baik serta layak jual); dan (2) mengetahui efektifitas model pembelajaran. Hasil penelitian pengembangan ini diharapkan dapat dimanfaatkan untuk mengatasi permasalahan pembelajaran praktik mahasiswa. Kompe- 
tensi dalam penelitian pengembangan ini mencakup aspek kognitif, afektif, dan psikomotorik.

\section{METODE}

Penelitian ini merupakan penelitian pengembangan yang berupaya membuat suatu produk baru dalam model pembelajaran. Penelitian ini berorientasi pada definisi yang dikemukakan Seels \& Richey (Richey \& Nelson, 1996), yakni penelitian pengembangan merupkan studi yang sistematis tentang perancangan, pengembangan pengevaluasian, program pengajaran, proses dan produk yang harus memenuhi kriterian konsistensi internal dan keefektifan. Penelitian pengembangan ini dilakukan pada program studi Pendidikan Teknik Mesin bidang keahlian Teknik Mesin Produksi di Fakultas Teknik Universitas Negeri Medan program S-1 pada mahasiswa yang mengambil mata kuliah Teknologi Pemesinan. Lokasi dan subjek penelitian ditetapkan secara purposive, dengan mempertimbangkan tahap-tahap penelitian serta tujuan khusus penelitian yang meliputi beberapa tahapan, dimana di dalamnya suatu produk dikembangkan, diujicobakan, dan direvisi sesuai hasil tes lapangan.

Urutan dalam penelitian dan pengembangan secara lengkap dalam Borg \& Gall (1983: 775) yang dilakukan meliputi 10 langkah, yakni: (1) research and information collection; (2) planning; (3) develop preliminary form of product; (4) preliminary field testing; (5) main product revision; (6) main field testing; (7) operational product revision; (8) operational field testing; (9) final product revision; dan (10) dissemination. Pada proses pengembangan dilakukan dengan mengadopsi langkah-langkah Borg \& Gall yang disesuaikan dengan kebutuhan pengembangan produk. Pilihan terhadap model ini karena diaggap sangat akomodatif terhadap pengembangan pembelajaran, namun mengingat langkahnya yang begitu pajang menyebabkan tidak memungkinkan untuk dilakukan secara penuh. Dengan demikian, pelaksanaan penelitian dilakukan hanya dengan mengadopsi step yang ada. Hal ini dapat dilakukan sesuai dengan ungkapan Gall, Gall, \& Borg (2003: 572) yang mengatakan bahwa pengembangan untuk kebu- tuhan disertasi dapat dikurangi beberapa langkah (step) dari siklus R\&D sesuai dengan kebutuhan, dengan mempertimbangkan secara matang waktu yang dibutuhkan untuk melakukan proses pengembangan.

Pengumpulan data dilakukan melalui studi pendahuluan, pengembangan, uji coba, dan uji validasi. Dalam setiap tahap penelitian, dipilih teknik pengumpulan data tertentu sesuai dengan tujuan masing-masing. Pada studi pendahuluan, dipilih teknik kuesioner/angket, observasi, dan dokumentasi, di samping kajian literatur (literature review). Pengumpulan data dilakukan melalui: angket/kuesioner, observasi dan wawancara. Uji coba model merupakan bagian yang sangat penting dalam penelitian dan pengembangan, yang dilakukan setelah rancangan pengembangan model pembelajaran selesai. Uji coba model bertujuan untuk mengetahui apakah model yang dikembangkan layak digunakan atau tidak. Uji coba model juga melihat sejauh mana produk yang dibuat dapat mencapai sasaran dan tujuan. Model yang baik memenuhi dua kriteria, yaitu kriteria pembelajaran (instructional criteria) dan kriteria penampilan (pesentation criteria). Uji coba dilakukan tiga kali, yaitu (1) uji ahli; (2) uji terbatas dilakukan terhadap kelompok kecil sebagai pengguna model; (3) uji lapangan (field testing). Dengan uji coba kualitas model yang dikembangkan betul-betul teruji secara empiris. Uji coba terbatas dan utama. Pada uji coba terbatas adalah observasi dan kuesioner. Kuesioner diberikan kepada dosen dengan tujuan untuk mengetahui apakah ada kendala dalam penerapan desain model pembelajaran. Pada uji validasi, teknik pengumpulan data yang digunakan adalah penilaian dampak penerapan model yang dikembangkan terhadap peningkatan kompetensi mahasiswa melalui perbandingan hasil pengukuran dalam penerapan model secara mandiri oleh kelompok kontrol dan eksperimen.

Instrumen penilaian kompetensi yang dikembangkan meliputi dua jenis, yaitu tes objektif dan tes tindakan. Dalam penyusunan atau pengembangan dua jenis tes ini, penulis bekerjasama dengan kelompok dosen yang mengampu secara langsung di kelas pada mata kuliah 
Teknologi Pemesinan. Ukuran validitas dan reliabilitas kedua tes tersebut didasarkan kepada validitas isi (content validity) dan pertimbangan ahli (experts judgement), salah satunya melalui pertimbangan dosen pengampu bidang keahlian. Penilaian kompetensi didasarkan pada hasil yang diperoleh pada aspek kognitif, afektif, dan psikomotorik dengan kategori: (1) nilai 90 s.d 100 sangat kompeten: (2) nilai 80 s.d 89 kompeten; (3) nilai 70 s.d 79 cukup kompeten; (4) nilai 55 s.d 69 belum kompeten; dan (5) nilai 0 s.d 54 tidak kompeten.

Teknik analisis data ini menggunakan analisis deskriptif kuantitatif. Semua data yang terkumpul dianalisis dengan teknik statistik deskriptif yang secara kuantitatif dipisahkan menurut kategori untuk mempertajam penilaian dalam menarik kesimpulan. Analisis data dalam penelitian pengembangan ini dijelaskan dalam tiga tahap, yaitu studi pendahuluan, pengembangan, dan validasi. Tahap pertama, studi pendahuluan, temuan atau fakta-fakta tentang pelaksanaan pembelajaran yang dilaksanakan saat ini dideskripsikan dalam bentuk sajian data (mean, median, modus), kemudian dianalisis (diinterpretasikan) secara kualitatif.

Analisis data yang digunakan dalam tahap penelitian pengembangan menggunakan deskriptif kualitatif. Tahap pengembangan dilakukan dengan beberapa pendekatan analisis, yaitu: (1) pelaksanaan dan hasil pengembangan desain model, dideskripsikan dalam bentuk sajian data, kemudian dianalisis secara kualitatif; (2) pada uji coba terbatas, hasil uji coba penerapan desain model dianalisis dengan pendekatan kuantitaif; (3) pada uji coba lebih luas, di samping menggunakan pendekatan analisis deskriptif kualitatif, juga digunakan analisis statistik (kuantitatif) dengan formula statistik uji-t (t-test) untuk mengukur hasil penerapan desain model. Tahap validasi, keberartian dan efektivitas hasil penerapan model dianalisis menggunakan pendekatan kuantitatif (quasi exsperimental) dengan membandingkan hasil pada kelompok (subjek penelitian) eksperimen dan kelompok kontrol pada kondisi sebelum dengan sesudah penerapan.

\section{HASIL DAN PEMBAHASAN \\ Hasil}

Berdasarkan hasil penelitian pendahuluan, analisis kebutuhan, kajian teoretik, validasi isi dan ahli desain model serta modul pembelajaran, uji coba terbatas dengan revisi model, uji coba utama dengan revisi, eksperimen pada uji coba utama/luas, yang telah dilakukan, dihasilkan produk model pembelajaran dan strategi pembelajaran serta modul pembelajaran yang dapat membantu dan memudahkan mahasiswa belajar pada bidang pendidikan teknologi permesinan. Hasil uji coba dengan revisi dan uji efektifitas produk dapat dijabarkan seperti berikut.

\section{Uji Coba Terbatas dengan Revisi}

Uji coba terbatas dengan revisi dilakukan pada 15 orang mahasiswa, bertujuan untuk mengetahui tingkat keterterapan model, serta kendala-kendala yang dijumpai dalam penerapan model. Dengan melakukan penilaian terhadap kelima aspek uji coba yang dirumuskan dalam setiap tahap uji coba, selanjutnya desain model pembelajaran dilakukan perbaikan dan penyempurnaan. Hasil uji coba terbatas dilakukan penilaian terhadap lima aspek seperti tersebut di atas, yaitu; (1) kualitas pembelajaran 72,35\%; (2) pelaksanaan pembelajaran $74,65 \%$; (3) metode pembelajaran $76,43 \%$; (4) penilaian mahasiswa terhadap desain model pembelajaran $73,45 \%$; dan (5) evaluasi hasil belajar mahasiswa 75,65\%

Hasil revisi ditunjukkan pada kesiapan yang dimiliki dosen dalam penggunaan model pembelajaran ini harus benar-benar dapat memberikan pembelajaran dalam bentuk teori maupun praktik dengan baik karena tugas yang dihasilkan oleh mahasiswa berupa produk harus berorientasi produksi. Dengan demikian, semua aspek tugas harus dapat diukur dan dinilai tingkat keberhasilannya. Secara keseluruhan, hasil kerja mahasiswa dalam uji coba terbatas sudah mengalamipeningkatan yang berarti, namun untuk selanjutnya terhadap pembuatan benda kerja dengan beberapa job yang harus dikerjakan mahasiswa sudah dapat menunjukkan peningkatkan kompetensi, baik dari ranah afektif, kognitif maupun psikomotoriknya. Hasil uji coba ter- 
batas tersebut digunakan sebagai bahan pertimbangan untuk melakukan perbaikan (revisi) terhadap desain model pembelajaran yang dikembangkan dan untuk selanjutnya dari hasil revisian pembelajaran digunakan sebagai perbaikan model pembelajaran untuk dilakukan uji coba utama.

\section{Uji Coba Utama dengan Revisi}

Uji coba utama dengan revisi dilakukan pada 20 orang mahasiswa selama empat kali uji coba dengan dua jenis benda kerja. Penentuan uji coba lebih utama didasarkan pada adanya kemungkinan kecenderungan perubahan dari setiap langkah secara signifikan yang mengarah pada keberhasilan dalam mengimplementasikan model pembelajaran. Selain itu, juga kendalakendala yang dijumpai dalam penerapan model pada skala yang lebih banyak, menilai keterterapan desain model, serta dalam rangka penyempurnaan desain model melalui penerapan ke beberapa subjek uji coba yang memiliki beberapa karakteristik yang bervariasi sesuai tujuan pengembangan sehingga ditemukan bentuk model pembelajaran yang cocok. Hasil uji coba lebih luas dilakukan penilaian terhadap lima aspek seperti tersebut di atas, yaitu; (1) kualitas pembelajaran $83,65 \%$; (2) pelaksanaan pembelajaran $84,45 \%$; (3) metode pembelajaran $80,56 \%$; (4) penilaian mahasiswa terhadap desain model pembelajaran $82,78 \%$; dan (5) evaluasi hasil belajar mahasiswa $85,76 \%$.

Hasil revisi ditunjukkan pada: (1) dosen mampu melaksanakan proses belajar mahasiswa dengan menggunakan strategi dan metode pembelajaran sesuai dengan tujuan kompetensi; (2) bahan pembelajaran praktik tersedia dan mampu menyediakan aneka stimuli dan fasilitas pembelajaran; (3) suasana belajar mendukung terciptanya kegiatan pembelajaran yang menarik, menantang, menyenangkan, dan berorientasi produksi bermakna bagi pembentukan kemandirian belajar mahasiswa; (4) media pembelajaran digunakan oleh dosen untuk meningkatkan intensitas belajar mahasiswa dalam peningkatan kompetensi; (5) proses pembelajaran praktik dengan menggunakan peralatan dan mesin-mesin per- kakas terciptanya situasi belajar yang aman, nyaman, dan menyenangkan; dan (6) modul pembelajaran proses produksi teknik pemesinan dan lembar kerja dalam bentuk job sheet, instructional sheet, operational sheet dan evaluation sheet. Oleh karena itu, kualitas model pembelajaran secara operasional dapat diartikan sebagai intensitas keterkaitan sistemik dan sinergis dosen, mahasiswa, kurikulum dan bahan pembelajaran, media pembelajaran, fasilitas praktik yang mendukung, dan sistem pembelajaran dalam menghasilkan proses dan hasil belajar yang optimal sesuai dengan tuntutan pendidikan dan kebutuhan dudi.

\section{Uji Efektivitas Produk}

Uji efektivitas produk berupa model pembelajaran yang bertujuan untuk mengetahui kefektifan model pembelajaran yang diterapkan. Hal tersebut dilakkan dengan cara melihat peningkatan hasil belajar mahasiswa yang menggunakan model pembelajaran yang dikembangkan dan model konvensional. Uji persyaratan analisis data penelitian dilakukan sebelum uji efektivitas model. Persyaratan yang dilakukan adalah dengan pengujian statistik melalui uji normalitas data dan diteruskan uji homogenitas. Hasil uji normalitas dan homogenitas sebaran data normal dan homogen pada taraf kepercayaan 5\%. Kompetensi mahasiswa kelompok eksperimen dan kontrol pada evaluasi kognitive skill proses produksi pemesinan diukur berdasarkan skor rata-rata hasil tes kognitif tertulis, yang menggambarkan pengetahuan dan pemahaman teknis mahasiswa terhadap materi sesuai kompetensi yang dipelajari dari tujuan pembelajaran yang dicapai. Pelaksanaan tes ini dilakukan satu kali, dengan asumsi bahwa hasil skor yang diperoleh benar-benar merupakan cermin kemampuan mahasiswa, bukan dipengaruhi oleh pengalaman mengerjakan tes kognitif yang berulang-ulang. Skor rata-rata hasil tes kognitif mahasiswa kelompok eksperimen dan kontrol diasumsikan tidak berbeda secara signifikan.

Data hasil belajar aspek kognitif bidang teknologi pemesinan dapat dilihat pada Tabel 1. 
Tabel 1. Deskripsi Kognitif Bidang Teknologi Pemesinan

\begin{tabular}{lccccccc}
\hline Kelompok & $\mathrm{N}$ & Rata-rata & Standar Deviasi & $\mathrm{dk}$ & $\mathrm{t}_{\text {hitung }}$ & $\mathrm{t}_{\text {tabel }}$ & Keterangan \\
\hline Eksperimen & 20 & 82,45 & 5,65 & 38 & \multirow{2}{*}{12,45} & \multirow{2}{*}{2,086} & \multirow{2}{*}{ Signifikan } \\
Kontrol & 20 & 76,56 & 5,78 & 38 & & & \\
\hline
\end{tabular}

Sumber: Data Primer yang diolah

Tabel 2. Deskripsi Praktek Mahasiswa Bidang Teknologi Pemesinan

\begin{tabular}{lccccccc}
\hline \multicolumn{1}{c}{ Kelompok } & $\mathrm{N}$ & Rata-rata & Standar Deviasi & $\mathrm{dk}$ & $\mathrm{t}_{\text {hitung }}$ & $\mathrm{t}_{\text {tabel }}$ & Keterangan \\
\hline Eksperimen & 20 & 83,65 & 3,56 & 38 & 21,67 & 2,086 & Signifikan \\
Kontrol & 20 & 78,34 & 3,87 & 38 & & & \\
\hline
\end{tabular}

Sumber: Data Primer yang diolah

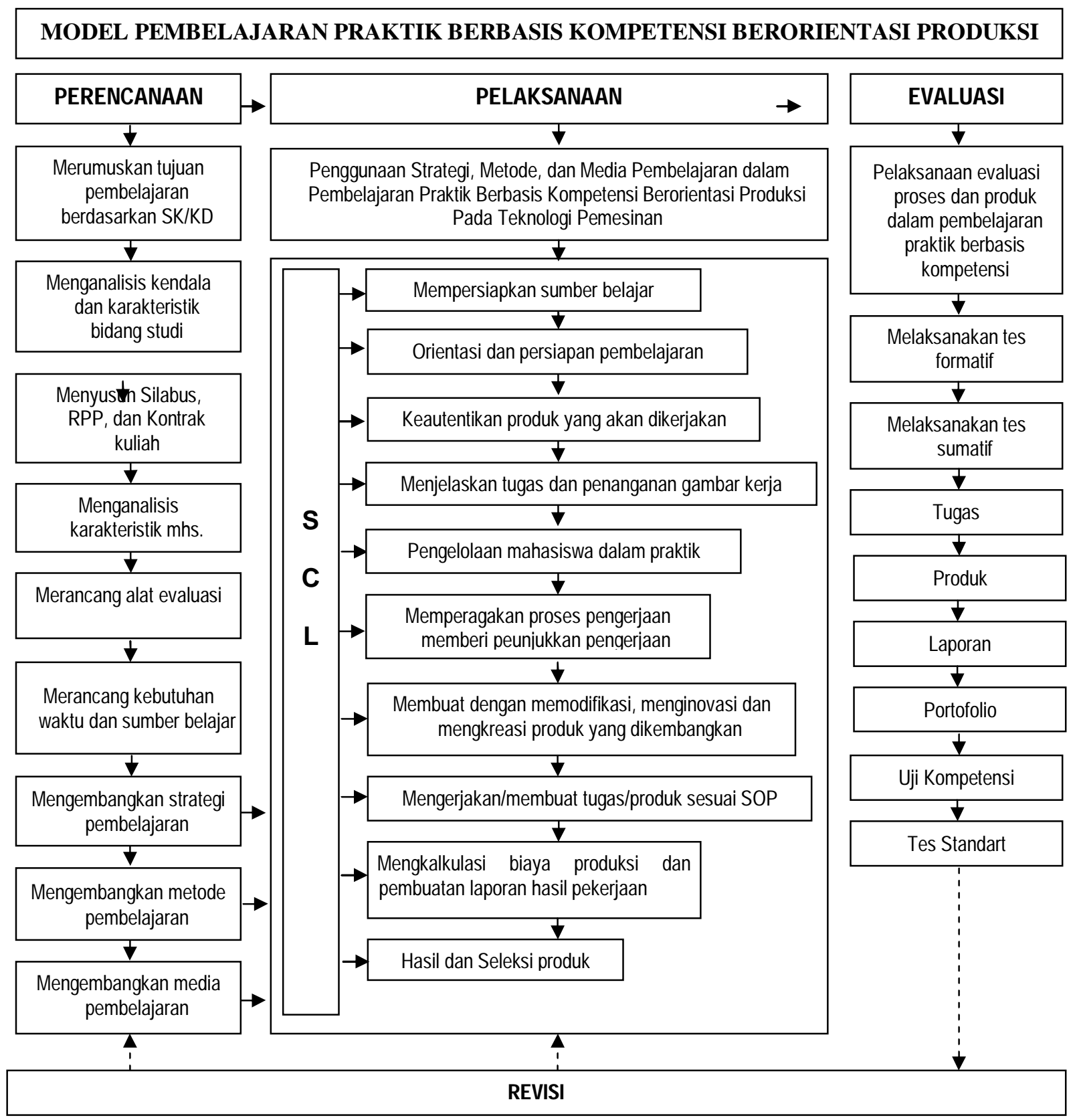

Gambar 1. Model Pembelajaran Praktik Berbasis Kompetensi Berorientasi Produksi 
Hasil pengujian statistik cognitive skill pada Tabel 1 menunjukkan bahwa rata-rata nilai mahasiswa kelompok eksperimen lebih tinggi daripada mahasiswa kelompok kontrol. Di samping itu, pada kelompok eksperimen tingkat kompetensi kognitif lebih merata dan homogen bila dibandingkan dengan kelompok kontrol. Berdasarkan hasil perhitungan statistik dengan uji-t, terdapat ada perbedaan yang signifikan antara kompetensi cognitive skill mahasiswa pada kelompok eksperimen dengan kelompok kontrol.

Data hasil belajar aspek kognitif bidang teknologi pemesinan dapat dilihat pada Tabel 2. Hasil pengujian statistik pada Tabel 2 menunjukkan bahwa kompetensi penilaian proses produksi teknik pemesinan dalam pembuatan benda kerja kelompok eksperimen lebih tinggi daripada mahasiswa kelompok kontrol. Di samping itu, pada kelompok eksperimen tingkat kompetensi penilaian proses produksi teknik pemesinan dalam pembuatan benda kerja lebih merata dan homogen bila dibandingkan dengan kelompok kontrol. Berdasarkan hasil perhitungan statistik dengan uji-t, terdapat perbedaan yang signifikan antara kompetensi dalam pembuatan benda kerjapada kelompok eksperimen dengan kelompok kontrol.

\section{Pembahasan}

Berdasarkan hasil validasi ahli bidang studi, desain pembelajaran dan hasil uji coba perorangan, uji coba kelompok kecil dan uji coba lapangan terhadap model pembelajaran yang dikembangkan menunjukkan bahwa model pembelajaran mampu memberikan nilai tambah, dan efektif dalam peningkatan kompetensi mahasiswa. Proses pembelajaran tersebut bertumpu pada penguasaan dan pemahaman materi dan praktik berkaitan dengan kompetensi yang diharapkan. Begitu juga hasil uji coba kelompok kecil dan lapangan menujukkan bahwa upaya pembelajaran mahasiswa agar dapat ditingkatkan, dikembangkan, sesuai dengan tujuan kompetesi yang diharapkan perlu adanya metode atau startegi pembelajaran yang dapat memudahkan mahasiswa belajar. Di samping itu juga dapat me- ningkatkan kemampuan aspek kognitif, afektif, maupun psikomotorik. Secara operasional pembelajaran prespektif memerlukan suatu pendekatan dalam penerapannya. Pendekatan tersebut di samping desain model yang dikembangkan, juga berfungsi untuk mengelaborasi aspek-aspek pada komponen pembelajaran, dan komponenkomponen metode dan strategi pembelajaran.

Pelaksanaan pembelajaran praktik pada uji coba utama terhadap kemampuan mahasiswa dapat meningkat. Hal ini juga ditunjukkan pada kemandirian dapat terbentuk sehingga tugas dosen adalah mengarahkan, memotivasi, memperlancar, dan mengevaluasi proses belajar mandiri mahasiswa melalui serangkaian kegiatan pembeajaran sehingga hal-hal yang bersifat konseptual akan menjadi ajang konfirmasi pemahaman mahasiswa terhadap materi dan tugas yang harus dikerjakan selama praktik berlangsung maupun di luar jam belajar. Dalam model pembelajaran, mahasiswa dituntut untuk mengerjakan sendiri tugas yang diberikan dengan petunjuk seperlunya yang diberikan oleh dosen, di samping juga sudah ada modul pembelajaran maupun lembar kerja. Dosen akan banyak menyampaikan kearifan (wisdom) daripada sekedar masalah teknis sehingga temu kelas mempunyai nilai tambah yang tinggi dan bermakna. Untuk mencapai itu semua, dosen dituntut memiliki kemampuan profesional dalam mengajar, memiliki keterampilan teknik yang baik dan pengembangan kompetensi yang terus dilakukan. Dosen harus selalu berupaya meningkatkan wawasan dan kinerja dalam rangka membantu mahasiswa untuk memperoleh hasil belajar yang optimal.

Hasil uji efektivitas produk yang dikembangkan terhadap kompetensi mahasiswa secara keseluruhan menunjukkan bahwa kelompok eksperimen dengan menggunakan model pembelajaran lebih tinggi rata-rata nilainya daripada mahasiswa dari kelompok kontrol (pembelajaran praktik konvensional). Hal ini menunjukkan bahwa penerapan dan pelaksanaan model pembelajaran dapat meningkatkan kompetensi mahasiswa, baik pada aspek afektif, kognitif, maupun psikomotoriknya. 
Hasil analisis terhadap model pembelajaran yang dikembangkan melalui uji coba terbatas dan uji coba utama pada semua aspek yang dinilai menunjukkan hal-hal seperti berikut. Pertama, kemudahan dipahami dan dimengerti dalam pelaksanaan pembelajaran dengan menggunakan model pembelajaran yang dikembangkan bagi mahasiswa. Kedua, menyenangkan, membuat bersemangat bekerja dan belajar, berkeinginan untuk berkembang, menjadi akrab, dan dapat melakukan kerjasama dengan baik bagi mahasiswa. Ketiga, dapat meningkatkan dalambelajar dan bekerja, dan meningkatkan kompetensi mahasiswa. Artinya, model pembelajaran yang dikembangkan cocok dan tepat karena sudah dapat mengapresiasi kebutuhan akan peningkatan kompetensinya sehingga dapat memberi kemudahan dalam pembelajaran praktik. Pelaksanaan pembelajaran dengan menggunakan model pembelajaran yang dikembangkan ini berdasarkan uji coba yang dilakukan dengan beberapa tahapan yang dilaksanakan dan memberikan kontribusi yang positif terhadap upaya peningkatan kompetensi mahasiswa. Upaya untuk mencapai hasil yang optimal dalam pembelajaran perlu kreativitas dosen dan mahasiswa sehingga memiliki perbedaan dengan pembelajaran lainnya.

Hal yang perlu ditekankan pada mahasiswa dalam pengembangan model pembelajaran yang diperoleh berdasarkan uji coba dan revisi produk adalah: (1) keterlibatan mahasiswa secara intelektual dan emosional dalam pembelajaran; (2) mahasiswa didorong untuk menemukan dan mengkonstruksi sendiri konsep yang sedang dikaji melalui berbagai cara seperti observasi, diskusi, percobaan, peniruan, pemahaman dalam membaca gambar kerja; (3) mahasiswa diberi kesempatan untuk bertanggung jawab menyelesaikan tugas; dan (4) mahasiswa harus bekerja keras, berdedikasi tinggi, dan antusias. Dengan cara tersebut, pembelajaran dengan model pembelajaran mampu memotivasi mahasiswa dalam melaksanakan berbagai kegiatan sehingga dapat menyelesaikan tugas-tugas secara kreatif.

Langkah-langkah yang ditempuh dalam upaya meningkatkan kompetensi mahasiswa melalui pengembangan model pembelajaran pada tahapan pelaksanaan validasi dan uji coba dan revisi seperti berikut. Pertama, adanya sumber belajar, baik berupa buku ajar dan teks, modul, rujukan, hand-out, lembar kerja (work sheet) meliputi: instructional sheet, operational sheet, job sheet, dan evaluation sheet, bahan kuliah yang berasal dari hasil penelitian pengembangan pembelajaran untuk mahasiswa. Kedua, memotivasi mahasiswa dengan memberi perhatian, memberi masukkan, memberi balikan, dan memberi penguatan belajar. Memberi materi yang relevan dengan tingkat kemampuan mahasiswa. Memberi semangat dan kepercayaan pada mahasiswa bahwa ia dapat mencapai kompetensi yang diharapkan. Memberi kepuasan pada mahasiswa terhadap pembelajaran yang kita jalankan. Ketiga, menunjukkan metode yang dapat membantu mahasiswa menelusuri dan menemukanpenyelesaian masalah. Keempat, memberikan umpan balik sebagai bentuk monitoring dan mengkoreksi hasil kinerja mahasiswa agar mencapai sasaran yang optimal sesuai kemampuannya.

Pelaksanaan pembelajaran dengan model pembelajaran dari beberapa tahapan uji coba dengan revisi menunjukan bahwa dosen harus mampu melakukan hal-hal seperti berikut. Pertama, menciptakan iklim belajar dan pembelajaran yang memposisikan mahasiswa sebagai centre learning (subjek pembelajaran) dengan segala aktivitas yang dilakukannya. Kedua, mengembangkan materi pembelajaran yang berwawasan produksi, yang bisa memotivasi belajar mahasiswa melalui ide-ide yang konstruktif pada diri dosen maupun mahasiswa. Ketiga, mendorong dan membangkitkan keberanian belajar dan bekerja yang didasarikomitmen yang tinggi dan berdisiplin. Dosen selalu dapat membimbing, mendorong, mengarahkan, memperbaiki, mengelola, mengorganisasikan pembelajaran dari seluruh rangkaian proses pembelajaran sehingga tercipta hubungan yang komunikatif dan harmonis yang bertujuan meningkatkan kompetensi mahasiswa secara lebih baik. Keempat, dosen mengemas materi pembelajaran yang sesuai dengan pengetahuan dan pengalaman mahasiswa serta masyarakat dudi. Hal ini sesuai dengan 
Pola Pengembangan Kurikulum Berbasis Kompetensi (2003:2) dengan orientasi baru pendidikan menjadikan lembaga pendidikan sebagai lembaga pendidikan kecakapan hidup, dengan pendidikan yang bertujuan mencapai kompetensi (selanjutnya disebut pembelajaran berbasis kompetensi), dengan proses pembelajaran yang otentik dan kontekstual yang dapat menghasilkan produk bernilai dan bermakna bagi mahasiswa, dan pemberian layanan pendidikan berbasis luas melalui berbagai jalur dan jenjang pendidikan yang fleksibel multi-entry-multi-exit.

Berdasarkan uji coba dan revisi terhadap materi pembelajaran yang sesuai dengan pengetahuan dan pengalaman akan mudah dipahami dengan baik melalui praktik langsung, sehingga orientasi pembelajaran tidak saja pada pemahaman dan penguasaan materi, tetapi juga pada penggunaan dan praktik kerja langsung. Hal ini juga sejalan dengan hasil penelitian yang dilakukan oleh Widanarko (2007:2) yang menyatakan bahwa model pembelajaran untuk memenuhi kompetensi dunia kerja ini harus menunjukkan: (1) kemampuan berkomunikasi ditingkatkan melalui pemberian tugas individu dan kelompok sejak awal perkuliahan; dan (2) kemampuan merencanakan dan merancang rekayasa di bidang permesinan ditingkatkan melalui pemberian rancangan pembelajaran, modul pembelajaran, materi tugas individu dan tugas kelompok.

Pengembangan model pembelajaran berbasis kompetensi, beberapa hal yang perlu dicermati berdasarkan revisi validasi ahli dan uji coba menunjukkan hal-hal seperti berikut. Pertama, proses pembelajaran praktik berlangsung, perencanaan pembelajaran harus sudah menjadi pegangan secara konsisten. Kedua, menetapkan keberhasilan belajar mahasiswa tidak saja dilihat dari hasil kerja atau hasil tugas/praktik, melainkan harus dinilai dari proses secara keseluruhan sehingga aspek yang dinilai dapat terjaring semuanya meliputi afektif, kognitif, maupun psikomotorik. Ketiga, proses pembelajaran, dosen harus mengoptimalkan penggunaan sumber belajar yang ada, seperti media pembelajaran interaktif, menarik dan dapat meningkatkan daya kreatif dan imajinatif mahasiswa agar pengetahuan dan keterampilannya meningkat. Partisipasi mahasiswa dalam proses pembelajaran dengan menggunakan model pembelajaran sangat dibutuhkan untuk melatih diri dan melibatkan diri dalam kegiatan pembelajaran agar kompetensinya meningkat. Nordhaug (1998:819) menyatakan bahwa kompetensi terdiri atas pengetahuan tentang metode, proses, dan teknik yang dirancang untuk melaksanakan tugas tertentu dan kemampuan menggunakan alat-alat dan perlengkapannya. Ini artinya kompetensi dalam pengertian spesifik dan teknis mencakup pengetahuan prinsip kerja dan prosedur kerja, serta kemampuan mengoperasikan alat untuk melaksanakan tugas atau pekerjaan tertentu. Menurut Sukmadinana (2004:151) bahwa penguasaan berbagai kompetensi tersebut, menjadi target atau sasaran yang harus dicapai dalam pembelajaran. Oleh karena itu, pembelajaran berbasis kompetensi bertujuan untuk mengembangkan kompetensi mahasiswa melalui strategi pembelajaran. Utamanya adalah mengidentifikasi tujuan-tujuan yang dapat diukur, menemukan rencana pembelajaran yang sesuai, dan menilai dengan tes kriteria, seberapa jauh mahasiswa mencapai kompetensi tertentu.

Kebutuhan akan penguasaan pengetahuan dan keterampilan praktik pada diri mahasiswa sangat diperlukan untuk mengetahui arah dan manfaat perkembangan pendidikan kejuruan ke depan dengan model pembelajaran yang dikembangkan. Didasari dengan taksonomi Gustafson (1981:78) yang membagi model-model pembelajaran menjadi empat kategori, yaitu model yang berorientasi pada: (1) kelas, (2) produk, (3) sistem, dan (4) organisasi. Menurutnya, model pembuatan produk mempunyai tiga karakteristik utama (1) adanya asumsi bahwa produk pembelajaran diperlukan; (2) diperlukan uji coba dan revisi berulang kali hingga mantap; dan (3) adanya asumsi bahwa produk itu harus dapat digunakan oleh berbagai pengelola pembelajaran. Hal ini didukung terhadap hasil penelitian Bruri (2005:296-297) dengan menggunakan model pembelajaran praktik yang cocok dengan menunjukkan peningkatan keterampilan tidak lepas dari keterampilan sejenis yang dibutuhkan dudi, untuk itu lembaga pendidikan tinggi dapat 
mengembangkan pembelajaran praktik dalam pembuatan benda kerja yang mengarah pada produk sesuai kebutuhan dudi atau berorientasi produk. Di samping itu, pembelajaran mesin perkakas yang sarat dengan peralatan presisi sebaliknya mempertimbangkan proses pembelajaran dengan pemilihan strategi yang sesuai dan dilakukan pengelompokkan kelas sesuai dengan tingkat bakat mekanik mahasiswa.

\section{PENUTUP}

Berdasarkan data dan pembahasan dari hasil penelitian dan pengembangan ini, dapat disimpulkan sebagai berikut.

Model pembelajaran praktik berbasis kompetensi berorientasi produksi yang dikembangkan layak digunakan dalam pembelajaran praktik yang ditunjukkan melalui: (1) validasi ahli materi, ahli desain pembelajaran, ahli desain grafis, secara keseluruhan menyatakan layak dan penerapan model pembelajaran dapat memberi kemudahan belajar mahasiswa pada pembelajaran praktik; dan (2) uji coba perorangan, uji coba terbatas, dan uji coba utama dengan berbagai persyaratan pengembangan yang dilakukan terhadap pelaksanaan uji coba menunjukkan bahwa model pembelajaran yang dikembangkan pada keterterapan model pembelajaran, strategi pembelajaran, metode pembelajaran dan bahan ajar yang dikembangkan dapat di terima dan mampu memberikan peningkatan kompetensi mahasiswa pada aspek afektif, kognitif, dan psikomotorik sehingga layak untuk digunakan dalam pembelajaran praktik.

Efektivitas model pembelajaran dalam penelitian dan pengembangan ini menunjukkan sebagai berikut. Pertama, hasil belajar mahasiswa dengan menggunakan model pembelajaran ini lebih efektif dibandingkan tanpa menggunakan model pembelajaran (konvensional) terhadap peningkatan kompetensi mahasiswa pada aspek afektif, kognitif, dan psikomotorik. Kedua, hasil belajar mahasiswa pada kelompok eksperimen dengan menggunakan model pembelajaran ratarata nilai lebih tinggi daripada hasil belajar pada kelompok mahasiswa pada pembelajaran konvensional. Ketiga, dapat meningkatkan kompetensi mahasiswa di bidang praktik pada pem- belajaran teknologi pemesinan secara bertahap dari hasil uji coba terbatas maupun uji coba utama. Keempat, secara keseluruhan terhadap produk yang dihasilkan oleh mahasiswa selama proses pembelajaran dengan menggunakan model yang dikembangkan menunjukkan kualitas yang lebih baik. Baik dalam waktu pengerjaan, sesuai SOP yang benar, metode, ketepatan, kualitas produk yang dihasilkan. Kelima peningkatan kualitas pembelajaran selama menggunakan model pembelajaran yang dikembangkan serta kesesuaian dengan materi yang diberikan yang berorientasi produksi selalu berkembang dan disesuaikan dengan kebutuhan masyakarat terhadap produk yang dikembangkan.

\section{UCAPAN TERIMA KASIH}

Penulis menyampaikan terima kasih kepada DP2M Dikti Kementerian Pendidikan dan Kebudayaan RI, dengan selesainya Hibah Bersaing Tahap III yang dibiayai melalui dana DIPA Unimed T.A. 2010 s.d 2012 Nomor: 0649/023-04.2.01/02/2012 Tanggal 09 Desember 2011, sebagai penunjang pelaksanaan penelitian ini. Kepada Pimpinan Universitas Negeri Medan, terima kasih telah memberi kesempatan kepada kami untuk melakukan karya ini. Penulis juga menyampaikan ucapan terima kasih yang sebesar-besarnya kepada Pengelola Jurnal Ilmiah Cakrawala Pendidikan Universitas Negeri Yogyakarta yang telah menerbitkan hasil penelitian ini.

\section{DAFTAR PUSTAKA}

Arends, Richard J. 2004. Learning to Teach. Boston, New York: McGraw-Hill Companies, Inc.

Borg, R, W, \& Gall, M, D. 1983. Educational Research an Introduction. Fourth Edition.New York : Longman

Bowden, J. \& Masters, G. 1993. Implications for Higher Education of A Competency Based Approach to Education and Learning. Canbera: AGPS. Prentice-Hall, Inc. 
Bruri, M. Triyono. 2005. "Pengaruh Strategi Pembelajaran dan Bakat Mekanik terhadap Keterampilan Mesin Perkakas CNC". Jurnal Teknologi Pendidikan. Vol. 7. No. 3 Desember, 2005.

Depdiknas. 2003. Pola Pengembangan Kurikulum Berbasis Kompetensi, Program Studi pada LPTK-PTK Jenjang S-1. Jakarta: Dirjendikti Dep. Pemb. PTK dan Ketenagaan PT.

Dick, Walter, Carey, Lou \&. Carey, James O. 2005. The Systemactic Design of Instruction. Boston: Pearson.

Gall, M.D, Gall, J.P. \& Borg W.R. 2003. Educational Research an Introduction, Seventh Edition. New York: Allyn and Bacon Publisher.

Gustafson, Kent L.1981. Survey of Instrucional Development Models. Syracuse, New York: Eric IR Document.

Gustafson, Kent L. \& Branch, Robert M. 2003. Survey of Instrucyional Development Models. Syracuse, New York: Eric IR Document.

HELTS 2003-2010. 2004. Strategi Jangka Panjang Pendidikan Tinggi, Mewujudkan Perguruan Tinggi Berkualitas. Jakarta: Depdiknas RI Dirjen Pend. Tinggi.

Joyce, Bruce \& Weil, Marsha. 1996. Model of Teaching. Boston: Allyn and Bacon $\mathrm{Pu}-$ blisher.

Khosrow, M. 2011. Instructional Design: Concept, Methodologies, Tools, and Applications .New York, Hershey: Information Science Reference.

Miarso, Yusufhadi. 2007. "Kontribusi Teknologi Pendidikan dalam Pembangunan Pendidikan." Makalah. Disampaikan dalam Seminar Internasional \& Temu Ilmiah FIP/JIP se-Indonesia. Manado.
Nordhaug, O. 1998. Competence Specificities in Organization. International Studies of Management and Organization, 1998, 28 (1).

Preston, B. \& Walker, J. 1993. Competency Standards in the Professions and Higher Education: a Holistic Approach. Canberra: Australian College of Education.

Prosser, C, A., \& Quigley, T, H. 1950. Vocational Education: in a Democracy. Chicago, U.S.A.: American Technical Society.

Reigeluth, Charles M. (ed). 1983. Instructional Design, Theories and Models: An Overview of Their Current Status. New Jersey: Lawrence Erlbaum Associates Publishers.

Richey, Rita \& Nelson. 1996. "Developmental Research". In Jonassen (Ed). Hand Book of Research for Educational Communicational and Technology. New York: Mc Millan Publishing Company.

Rothwell, William J. \& H.C. Kazanas. 2004. Mastering The Instructional Design Process. Third Edition. San Francisco: Pfeiffer.

Seels, Barbara B. \& Richey, Rita C. 1994. Teknologi Pembelajaran Definisi dan Kawasannya, Terjemahan Dewi, Rapheal, Yusufhadi Miarso. Jakarta: Unit Percetakan UNJ.

Sukmadinata, Nana Syaodih. 2004. Kurikulum dan Pembelajaran Kompetensi. Bandung: Kesuma Karya.

Unimed. 2004. Pedoman Pengembangan Standar Mutu Lulusan dan Kurikulum Berbasis Kompetensi. Medan: Universitas Negeri Medan.

Widanarko, Sulistyoeweni. 2007. "Model Pembelajaran Bidang Ilmu Teknik Mesin dalam Upaya Meningkatkan Efektifitas dan 
Efisiensi Pendidikan Tinggi: Suatu Model Pembelajaran untuk Memenuhi Kompetensi Dunia Kerja yang Perlu Ditingkatkan Pada Perguruan Tinggi di Bidang Ilmu Teknik Mesin". http://www.digilib.ui.ac.id/opac/themes/libri2/detail.jsp?id= 76094. (Diunduh 16 Maret 2012).
Wilson,G. Brent. 1996. Constructivist Learning Environment Educational Technology. New Jersey: Publications Englewood Cliffs. 